\title{
THE ROLE OF HIGHER EDUCATION SYSTEM IN PROVIDING THE BALANCE OF THE LABOUR MARKET
}

Rakhmonov Norim Razzakovich - the chief specialist of the Ministry of Higher and Secondary Special Education of the Republic of Uzbekistan,

Researcher at National University Republic of Uzbekistan navruza_yaxyayeva@mail.ru

\section{Crossref} http://dx.doi.org/10.26739/2433-202x

Issue DOI http://dx.doi.org/10.26739/2433-202x-2017-8-8

Article DOI http://dx.doi.org/10.26739/2433-202x-2017-8-8-2

Abstract: This article describes the role and functions of higher education in the development of the national economy and the employment and share it with high personnel aspects. Several directions are stated due to solve the problems of the formation of the market of educational services in Uzbekistan.

Keywords: higher education, labor market, employment, expanded production, "three ring".

It was reported that the country's population with employment, higher education institutions to improve the quality of personnel, to ensure the balanced development of the regions on employment is carried out on a wide range of reformations. Cooperation with employers, graduates and young Social science and humanities

N. Rakhmonov 
professionals work placement of graduates, which is one of the components of the process of monitoring the scheme has been developed and higher education institutions were invited to the event. The sequence of directions, regulated, and participants include: marketing department, authorities, agencies, labor exchanges, institutions of higher education were brought to the vice-rector, and the functional connections between them.

At the same time the main objective of the institution of higher education as well as to the real sectors of the economy to a high-quality expert training university graduates with the knowledge, skills and abilities in accordance with the requirements of state educational standards to the level of higher education institutions in order to assess a complex final state certification. This process is simultaneously regulated with "the "Regulations on the final state certification of graduates of higher education institutions of the Republic of Uzbekistan"1.

One of the peculiarities of the current period, is the "human factor" is moved to the theoretical and practical aspects of a person's quality problems, producing and using labor force training .

It is known that the theory of reproduction of general economic processes taking place in society are overviewed in coherence, goods are always updated with the increase in the number and quality .Reproduction means the existence of society and the foundation of the development.

It should be specifically noted that, with the development of the education system, labor force reproduction connection exists between the lens and it holds a special place in the system of social reproduction problems. This case shows that the power of the labor force is the primary producer.

Among the results of social reproduction, first of all, education should highlight the positive impact of the human personality. The education system is the main producer of the society as a human being fully competent and well-educated, professional training and constantly improves, and in different directions by way of improving. The purpose of the formation of labor force means to improve his knowledge and skills. It is known that the main reason for achieving economic growth of the country depends on the productivity of all factors of production. However, all the factors on its ability to work is of vital importance. First, labor is the source of goods and the

1 "Regulations on final state certification of graduates of higher educational institutions of the Republic of Uzbekistan" - Collection of legislation of the Republic of Uzbekistan. - 2009. - No. 23. - Article 267.

Social science and humanities

N. Rakhmonov 
increase of services. Second, the only force in accordance with the combination of other factors can create a favor to satisfy the needs of the people. In addition, any other factors cannot fulfill this task.

Thus, the education system, the role of the re-production of a qualified work force, first as a condition of development of the person that it will be directly involved in the formation of the labor force.

The role of the education system in reproduction of skilled labor force is expressed in competent and knowledgeable, and continuous improvement of their professional skills and a variety of directions will show their progress and improve. This is primarily related to the need to increase the effectiveness of the continuous reproduction.

G.Inkovit and Layton Liedistdorf put forward by the "Universityindustry-government innovation", ie, "three ring" mechanism in providing for the optimal operation of the industrial sector of the economy, the number of personnel operating in the real sector play an important role'2.

The negative consequences of the global financial and economic crisis, the modernization of the economy in order to prevent its economic impact, diversification important role in the structure of the network. This in turn will increase the efficiency of labor sources. System of higher education institutions need to increase the quality of experts grown.

Working to improve the strength of this system is carried out at three levels:

The first level of functional illiteracy eradication, education, regular workforce. He is the man of the blessings of modern civilization; the software allows you to do simple enterprises.

- Second reading and re-reading age, new knowledge can transform a place to live and work with independent access sophisticated workforce. Furthermore, human development, and professional, regional and social mobility, and the formation of self-control. This process of knowledge accumulation of the means of achieving it.

- Third degree of preparation of the scientific and technical work force, not only in the world, capable of introduction of innovations in the development of the results of science refers to the preparation of the scientific and technical work force.

2 wWw.wikipedia.org

Social science and humanities

N. Rakhmonov

Japan, Osaka 
It should be noted that the description of the use of labor and reproduction problems, and solution of social problems in the country ultimately depends on the extent of this problem have been found.

First of all, the material basis of the production of skilled workforce in various sectors and spheres of their labor income. He is a person's skills, knowledge, training and activities must be in accordance with the results. In developed countries, this compatibility is provided in the following sequence: a high level of knowledge, training and skills, efficient labor, income, living level. Therefore, human knowledge, professions, and finally it again basic material for the production, determines the level of income and welfare. In addition, the different stages of a market economy phase inevitably remain in unemployment. "In order to prevent the occurrence of serious problems in the social sphere, providing the government with regular citizen's policy, friction, and structural unemployment will teach grow again, expand the education system" 3 .

Therefore, the education system is in the process of reproduction of a qualified work force, which formed the basis of the material and the quality of its direct impact on the formation of a direct effect on the amount of income.

It should be noted that the education system is a priority developed qualified to fill the role of the labor force in the development of the economy. At the same time the country's productive forces is an important subject, implementers and users of services.

Regions on the location of labor resources, economic specialization of regions and economic sectors of potential staff in keeping stability in the economy of the region effectiveness resulting factor (Figure 1).

${ }^{3}$ Abdurakhmanov Q. Economics and sociology of labor.-Tashkent: Teacher, 2001. -P. 91.

Social science and humanities

N. Rakhmonov 


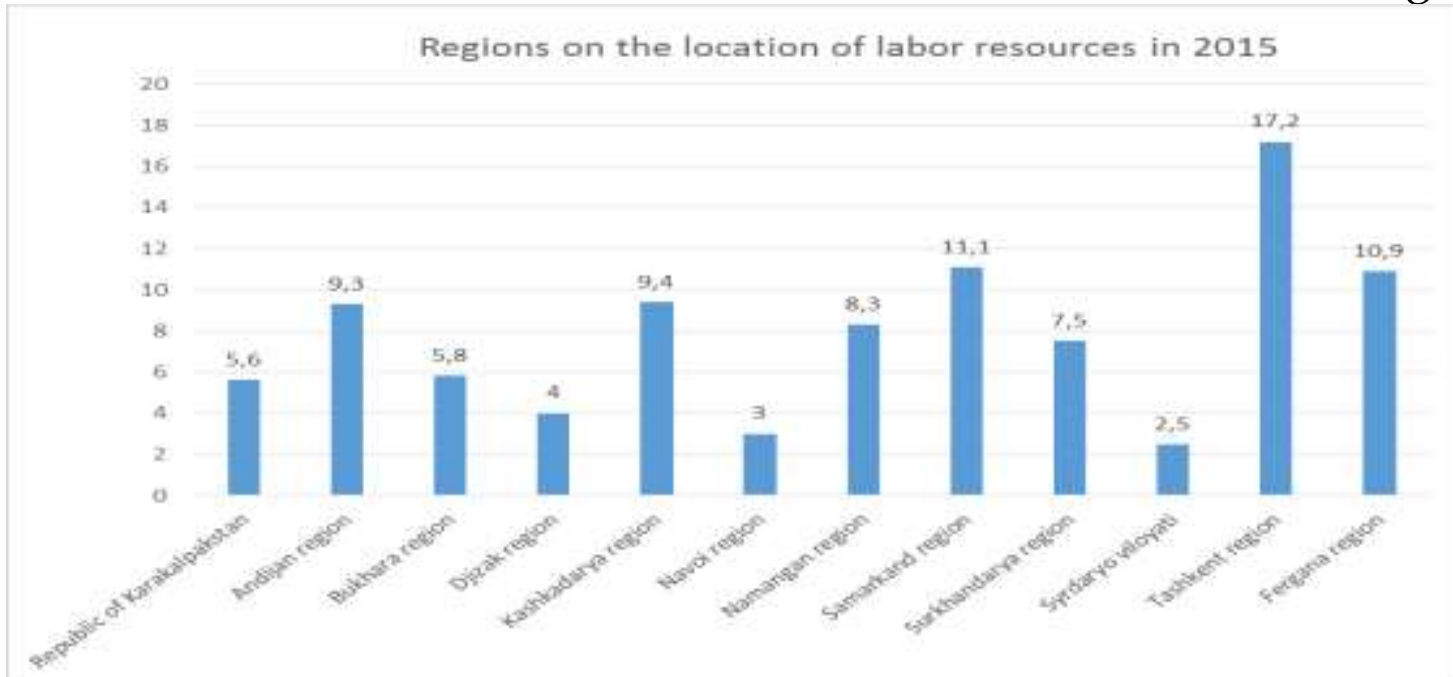

You can see the disproportionate number of them on the distribution of labor resources Gulf examined. This demographic migration zones on the location of the system of higher education and training program to ensure the employment of higher education graduates, the role of the distribution (Figure 1).

The above diagram labor resource disparities among regions, demographics, population, internal and external factors, such as labor migration impact.

To create a reserve based on the demand of the labor market, vocational training, education, and the development of the service sector, the implementation of the National program for cadres training need to expand the scope of foreign investment. To explore the prospects for the development and regulation of the labor market, the need for labor market forecasting, economic aspects and potential role in determining the amount of unemployment.

The assessment of the labor market regions of the country and its socioeconomic and demographic factors that embodies lies in the economic indicators. The labor market forecasting and harmonization between the minimum and maximum level of local employment service staff to study the situation on the regional labor market and the prospects for the labor market to establish the regulation of the balance of this level is an important scientific and practical significance (Figure 2).

\footnotetext{
4 Prepared by the author on the basis of data from the State Statistics Committee of the Republic of Uzbekistan
}

Social science and humanities

N. Rakhmonov 


\section{The distribution of}

labor resources on employment in 2015

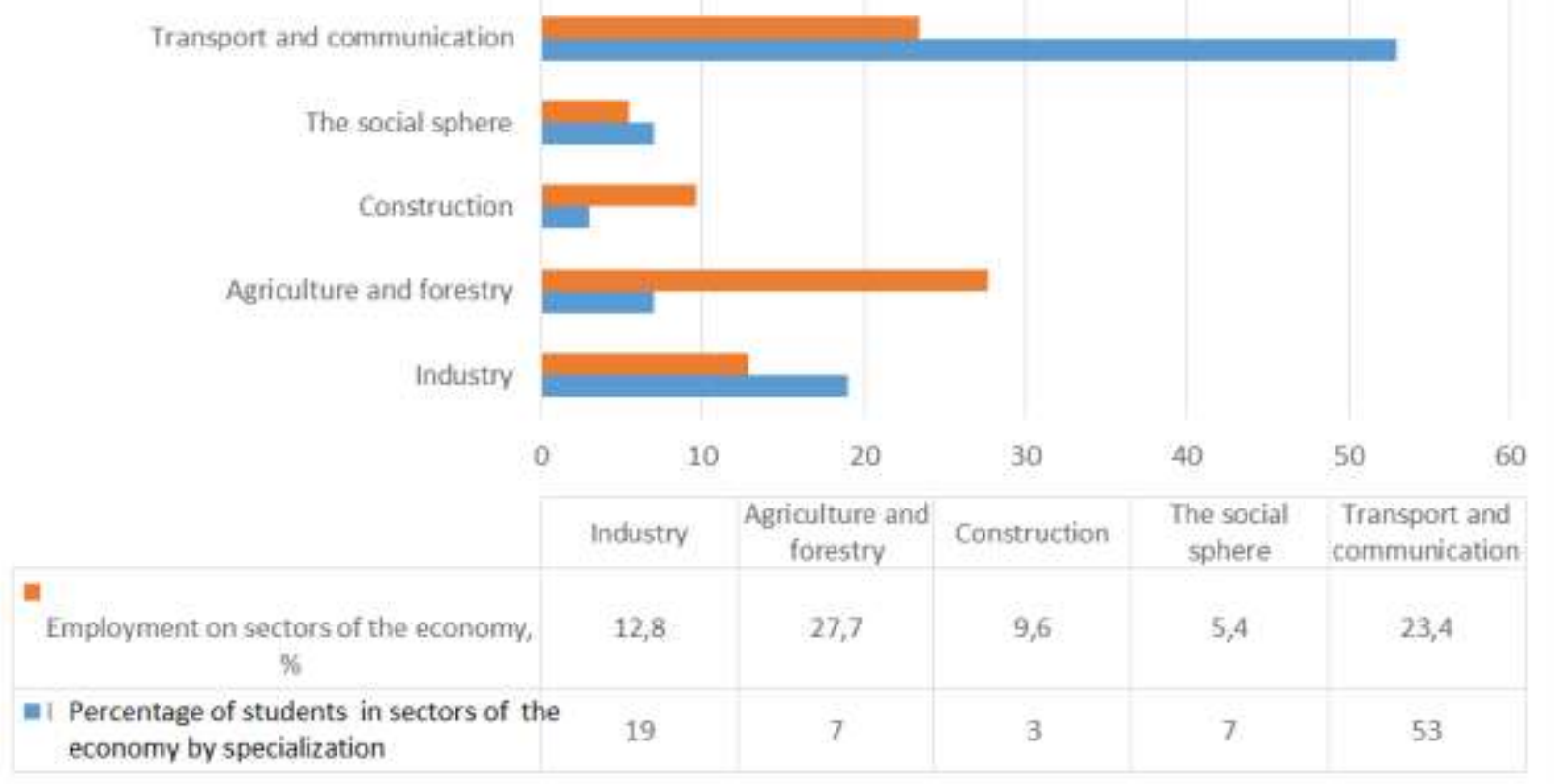

2015 which focused on the structure of the industrial sector of the economy, according to the share of the labor force $(12.8 \%)$ and higher education institutions, industry specialized students $(19.0 \%)$, the difference between the occurrence of a number of objective and subjective factors are a result of the impact.

The role of the industrial sector created a working sectors of the economy to create new jobs in the area. In particular, the automotive industry around the creation of a new role in his own serve him seven jobs. One of the most important factors in the development of the industrial sector of the global financial and economic crisis continued to have a system of higher education in the conditions of the need to improve the quality of personnel in the area. Indeed, the development of competitive pan and services, the introduction of innovative news developments to practice opportunities more widely.

The modernization of the economy and socio-economic reforms in higher education institutions in the implementation of specialization, students entering the labor market that is increasingly competitive and

5 "Education in Uzbekistan" State Committee of the Republic of Uzbekistan on Statistics: Tashkent-2015

Social science and humanities

N. Rakhmonov 
quality of human resources through the improvement of the production balance a positive impact on the labor market and social and economic stability. The important role of the following:

In conclusion, and in the context of modernization specialization in higher education institutions in the preparation of regional network diversification further deepening of the study and their future forecasts of labor resources in providing for the regional imbalance on the labor market, measures to improve the labor conditions of domestic labor of migration organize further expansion of the higher education system of HR training measures to improve the quality of production provides the stability of the labor market. 


\section{References}

1. "Education in Uzbekistan" State Committee of the Republic of Uzbekistan on Statistics: Tashkent-2015

2. Zharov VS, Shcheglova AN, Regional features of the development of higher professional education in the north of Russia, ж-л. Fundamental research, Issue No. 4-1 / 2013, p.198

3. "Provision on the final state certification of graduates of higher educational institutions of the Republic of Uzbekistan" - a package of legislative acts of the Republic of Uzbekistan. - 2009. - No. 23. - Article 267

4. Vaskolovich H.A. Economics of paid services / N.A. Voskolovich. -: UnityDana, 2009. P .399.

5. Abdurahmonov K. The Economy of Labour and Sociology. -Toshkent: O’qituvchi, 2001. -p 91 